\title{
Protective effects of Kolaviron and Gallic acid against cobalt chloride induced cardio-renal dysfunction via suppression of oxidative stress and activation of ERK signaling pathway
}

\begin{tabular}{|r|l|}
\hline Journal: & Canadian Journal of Physiology and Pharmacology \\
\hline Manuscript ID & cjpp-2016-0197.R1 \\
\hline Manuscript Type: & Article \\
\hline Complete List of Authors: & $\begin{array}{l}\text { Akinrinde, Akinleye; University of Ibadan, Department of Veterinary } \\
\text { Physiology, Biochemistry and Pharmacology; University of Fort Hare, } \\
\text { Department of Biochemistry and Microbiology } \\
\text { Omobowale, Olutayo; University of Ibadan, Department of Veterinary } \\
\text { Medicine } \\
\text { Oyagbemi, Ademola; University of Ibadan, Department of Veterinary } \\
\text { Physiology, Biochemistry and Pharmacology } \\
\text { Asenuga, Ebunoluwa; University of Benin, Department of Veterinary } \\
\text { Biochemistry } \\
\text { Ajibade, Temitayo; University of Ibadan, Department of Veterinary } \\
\text { Physiology, Biochemistry and Pharmacology }\end{array}$ \\
\hline \hline Keyword: & Heart, Kidneys, Kolaviron, Gallic acid, Cobalt \\
\hline
\end{tabular}


Protective effects of Kolaviron and Gallic acid against cobalt chloride induced cardio-renal dysfunction via suppression of oxidative stress and activation of ERK signaling pathway

Akinrinde Akinleye Stephen ${ }^{1 *}$, Omobowale Olutayo ${ }^{2}$, Oyagbemi Ademola ${ }^{1}$, Asenuga Ebunoluwa ${ }^{3}$ and Ajibade Temitayo ${ }^{1}$

${ }^{1}$ Department of Veterinary Physiology, Biochemistry and Pharmacology, Faculty of Veterinary Medicine, University of Ibadan, Nigeria.

${ }^{2}$ Department of Veterinary Medicine, Faculty of Veterinary Medicine, University of Ibadan, Nigeria.

${ }^{3}$ Department of Veterinary Biochemistry, Faculty of Veterinary Medicine, University of Benin, Nigeria

\section{*Correspondence:}

Dr. Akinrinde Akinleye Stephen, Department of Veterinary Physiology, Biochemistry and Pharmacology, University of Ibadan, Nigeria.

E-mail: 201514802@ufh.ac.za; levesteve2000@yahoo.com 


\begin{abstract}
Cobalt (Co) toxicity is a potential public health problem due to recent renewed use of Co in orthopedic implants, dietary supplements and blood doping in athletes and horses. We investigated the protective roles of Kolaviron, KV (a bi-flavonoid of Garcinia kola) and Gallic acid (GA) on cobalt chloride $\left(\mathrm{CoCl}_{2}\right)$ - induced cardio-renal damage in rats. $\mathrm{CoCl}_{2}$ caused significant increases $(p<0.05)$ in serum creatine kinase-myocardial band $(\mathrm{CK}-\mathrm{MB})$, lactate dehydrogenase (LDH), aspartate transaminase (AST), xanthine oxidase (XO), urea, creatinine, malondialdehyde, $\mathrm{H}_{2} \mathrm{O}_{2}$, nitric oxide, as well as C-reactive protein expression, along with significant $(\mathrm{p}<0.05)$ reduction in cardiac and renal expression of extracellular signal regulated kinase (ERK) and the activities of superoxide dismutase, catalase and glutathione S-transferase. $\mathrm{KV}$ and GA prevented the toxic effects of $\mathrm{CoCl}_{2}$ by stimulating ERK expression and reversing Co-induced biochemical changes. Administration of $\mathrm{CoCl}_{2}$ alone did not significantly alter ECG patterns in the rats, although co-treatment with KV (200 mg/kg) produced QT-segment prolongation and also appeared to potentiate Co-hypotension. Histopathology of the heart and kidneys of rats treated with KV and GA confirmed the biochemical data. Kolaviron and Gallic acid thus protected against cardiac and renal damage in cobalt-intoxication via antioxidant and/or cell survival mechanisms, possibly involving ERK activation.
\end{abstract}

Keywords: Cobalt, Heart, kidneys, Kolaviron, Gallic acid, oxidative stress, ERK, ECG. 


\subsection{Introduction}

Cobalt has been used historically in the treatment of pernicious anemia, due to its ability to stimulate the production of red blood cells and hemoglobin (Barceloux 1999). It was also employed in the 1960s as a foam stabilizer in beers (Alexander 1972). The use of this metal in these situations had been accompanied by toxic effects namely thyroid dysfunction in children and cardiomyopathies in some heavy beer drinkers (Paustenbach et al. 2013). The introduction of more efficacious drugs in the treatment of anemia and the occurrence of adverse effects led to the termination of cobalt use in these situations decades ago.

Recent concerns over cobalt toxicity have emerged from its potential use as a blood doping agent in humans and animals (Jelkmann and Lundby 2011; Lippi et al. 2006; Mobasheri and Proudman 2015), as well as its use in surgical patients with Co-containing hip implants (Hasegawa et al. 2012; Macnair et al. 2012). Furthermore, intense mining activities in certain areas have led to environmental contamination with potential widespread exposures to cobalt (Banza et al. 2009; Cheyns et al. 2014). The consumption of cobalt-containing dietary supplements is also believed to be on the rise in different parts of the world (Tvermoes et al. 2013).

Formation of reactive oxygen species, leading to oxidative stress and lipid peroxidation has been shown to be one of the major pathogenetic mechanisms for cobalt-induced tissue injuries (Ahmed and Siddiqui 2007; Catelas et al. 2005; Franco et al. 2009; Kubrak et al. 2011). Oxidative processes result in post-translational modifications of a variety of proteins including kinases (e.g. extracellular signal-regulated kinase, ERK; p38); proteases (e.g. caspases) and transcription factors (e.g. NF-кB, AP-1, p53, Nrf 2) (Franco et al. 2009; Son et al. 2011). These proteins regulate diverse biochemical and cellular functions, ranging from cell survival to cell death (Haagenson and $\mathrm{Wu} 2010)$. 
Antioxidants may act directly by scavenging reactive oxygen and nitrogen species (ROS/RNS) via direct consumption or chemical modification. Alternatively, antioxidants may act indirectly by controlling gene expression during oxidative stress by up-regulating phase II detoxifying and antioxidant enzymes (Kim and Jang 2014). Stimulation of these enzymes usually occurs by the activation of nuclear transcription factor-erythroid 2-related factor 2 (Nrf-2) via its release from Kelch-like ECH-associated protein 1 (Keap 1)-Nrf-2 complex (Park et al., 2004). In addition, Keap 1-independent activation of Nrf-2 can occur by its phosphorylation by several signal pathways involving ERK, phosphatidyl inositol 3-kinase (PI3K/Akt) and protein kinase C (PKC) (Baird and Dinkova-Kostova 2011; Itoh et al. 2004)

Flavonoids have found valuable therapeutic and prophylactic applications due to their excellent free radical scavenging activities (Havsteen 2002) and their ability to induce the expression of detoxifying and antioxidant enzymes (Hormann et al. 2011; Mann et al. 2009). Kolaviron (KV) is a de-fatted extract from bitter kola (Garcinia kola) seeds, widely reported to contain Garcinia biflavonoid 1 (GB1), Garcinia biflavonoid 2 (GB2) and kolaflavanone (Figure 1a). Its antioxidant and anti-inflammatory actions have been employed to protect against many pathological conditions (Adedara and Farombi 2012; Olaleye et al. 2000). Its cardio protective (Adaramoye and Lawal 2015) and nephro-protective (Adedara et al. 2015) actions have been reported. Gallic acid (Figure 1b) is an endogenous plant phenol that is found in many fruits, teas and wine (Ma et al. 2003; Singh et al. 2004). It has been widely reported for its strong antioxidant (Kroes et al. 1992), anti-inflammatory (Kim et al. 2002) and cardio-protective properties (Priscilla and Prince 2009).

In the present study, we attempted to evaluate the cardio- and nephro-protective effects of Kolaviron and Gallic acid on cardiac and renal damage induced by cobalt chloride administration 
in rats. We attempted to demonstrate the possible mechanisms of the therapeutic efficacies of these compounds by studying the biochemical markers of injury to cardiac and renal tissues, antioxidant defense system, electrocardiographic and histopathological changes, as well as immunohistochemical staining patterns of a key signaling protein, ERK.

\subsection{Materials and methods}

\subsection{Chemicals}

Cobalt chloride hexahydrate $(\mathrm{CoCl} 2.6 \mathrm{H} 2 \mathrm{O})$ was obtained from Tianjin Kermel $^{\circledR}$ Chemical Reagent Co, China. Gallic acid, Glutathione, 1, 2-dichloro-4-nitrobenzene (CDNB), thiobarbituric acid (TBA), trichloroacetic acid (TCA), sodium hydroxide, xylenol orange, potassium hydroxide and hydrogen peroxide were purchased from Sigma (St. Louis, MO, USA). All other chemicals were of the highest purity commercially available.

\subsection{Extraction of Kolaviron}

Seeds of Garcinia kola were obtained from a local vendor in Ibadan, Nigeria. They were identified at the Department of Botany herbarium, University of Ibadan, Nigeria. The seeds were peeled, sliced, and dried at room temperature $\left(25-28^{\circ} \mathrm{C}\right)$. Kolaviron was extraction according to the method of Iwu et al. (1985).

\subsection{Animal treatment and Experimental design}

Male Wistar rats aged between 10 and 12 weeks (180-200g) were obtained from the Experimental animal Unit, Faculty of Veterinary Medicine, University of Ibadan, Nigeria. They were housed in plastic cages placed in a well-ventilated animal house and were given ad libitum access to rat chow (Ladokun Feeds Ltd, Ibadan, Nigeria) and subjected to natural photoperiod of 
12-h light : dark cycle. All the animals received humane care according to the criteria outlined in the 'Guide for the Care and Use of Laboratory Animals' prepared by the National Academy of Science and published by the National Institute of Health. The ethic regulations have been followed in accordance with national and institutional guidelines for the protection of animal welfare during experiments (Public Health Service, PHS 1996).

The rats were divided randomly into five groups of 8 rats each. Group A received clean tap water only, while Group B were treated with cobalt chloride $\left(\mathrm{CoCl}_{2}, 350 \mathrm{ppm}\right)$ in drinking water for 14 days. Group C and D rats were orally treated by gavage with 100 and $200 \mathrm{mg} / \mathrm{kg}$ Kolaviron (KV1 and KV2), respectively, along with $\mathrm{CoCl}_{2}$ treatment in drinking water. Group E rats were treated by oral gavage with $120 \mathrm{mg} / \mathrm{kg}$ Gallic acid and also with $\mathrm{CoCl}_{2}$ in the same manner as groups C and D. The doses of cobalt chloride, Kolaviron and Gallic acid have been carefully chosen based on previous studies (Farombi et al. 2012; Garoui et al. 2011, 2012; Oyagbemi et al. 2015).

\subsection{Electrocardiography}

Standard lead II electrocardiogram was recorded in rats immobilized with xylazine/ketamine combination using a 6/7-lead ECG machine (EDAN VE-1010, Shanghai, China). The machine was calibrated at $20 \mathrm{~mm} / \mathrm{mV}$ paper speed and $50 \mathrm{~mm} / \mathrm{s}$ paper speed. From the electrocardiogram, parameters such as heart rate, PR interval, QRS wave duration, R-wave amplitude and QT/QTc values were determined.

\subsection{Blood pressure measurements}


After all the treatments, indirect blood pressure parameters, including systolic (SBP), diastolic (DBP), and mean arterial (MAP) blood pressures were determined without anesthesia, by tail plethysmography using an electrosphygmomanometer (CODA, Kent Scientific, USA). The average of at least nine readings, taken in the quiescent state, following acclimatization, was recorded per animal.

\subsection{Animal necropsy and tissue preparation}

Blood was drawn from the retro-orbital plexus into plain vials prior to sacrifice. All rats were sacrificed by cervical dislocation, twenty four hours after the last treatment. The heart and kidneys were quickly removed, rinsed in $1.15 \% \mathrm{KCl}$ and homogenized in potassium phosphate buffer (0.1 M, pH 7.4), and homogenates were centrifuged at 10,000 g for 20 minutes to obtain the post-mitochondrial supernatant which was maintained at $-4^{\circ} \mathrm{C}$ used for the biochemical assays. The collected blood was allowed to clot and the samples were centrifuged at 3,000 $\mathrm{g}$ for 10 minutes. Serum was collected as the supernatant and was also used for some biochemical assays.

\subsection{Determination of cardiac and renal oxidative stress and antioxidant markers}

Protein concentration was determined using the Biuret method according to the method of Gornal et al. (1949). Hydrogen peroxide $\left(\mathrm{H}_{2} \mathrm{O}_{2}\right)$ generation was determined spectrophotometrically at 560nm as described by Wolff (1994). Lipid peroxidation was evaluated by estimating malodialdehyde (MDA) using the method of Varshney and Kale (1990). MDA content was quantified with a molar extinction coefficient of $1.56 \times 105 \mathrm{M}^{-1} \mathrm{~cm}^{-1}$ and expressed as micromole per gram tissue. Superoxide dismutase (SOD) activity was determined 
by measuring the inhibition of the auto-oxidation of epinephrine at $\mathrm{pH} 7.2$ at $30^{\circ} \mathrm{C}$ as described by Misra and Fridovich (1972) with slight modifications from our laboratory Oyagbemi et al. (2015). Briefly, $100 \mathrm{mg}$ of epinephrine was dissolved in $100 \mathrm{ml}$ distilled water and acidified with $0.5 \mathrm{ml}$ concentrated hydrochloric acid. $0.01 \mathrm{ml}$ of each sample was added to $2.5 \mathrm{ml}$ of $0.05 \mathrm{M}$ carbonate buffer ( $\mathrm{pH}$ 10.2) followed by the addition of $0.3 \mathrm{ml}$ of $0.3 \mathrm{mM}$ epinephrine. The increase in absorbance at $480 \mathrm{~nm}$ was monitored every 30 seconds for 150 seconds. 1 unit of SOD activity represents the amount of SOD necessary to cause $50 \%$ inhibition of the oxidation of adrenaline to adrenochrome during 1 minute. The concentration of GSH was determined at $412 \mathrm{~nm}$ using the method described by Jollow et al. (1974). Glutathione-S-transferase (GST) activity was estimated by the method of Habig et al. (1974) using 1-chloro-2, 4-dinitrobenzene (CDNB) as substrate. Catalase (CAT) activity was determined according to the method of Sinha (1972). Nitric oxide (NO) content (NO) was measured as described by Olaleye et al. (2007) by indirectly measuring the nitrite concentration. The activity of xanthine oxidase in serum was determined according to method of (Akaike et al. 1990).

\subsection{Evaluation of markers of cardiac and renal injury}

Activities of creatine kinase myocardial band (CK-MB), lactate dehydrogenase (LDH) and aspartate transaminase (AST) and the concentrations of urea and creatinine in serum were assayed in in serum using commercial kits purchased from Randox Laboratories Ltd (Crumlin, UK).

\subsection{Immunohistochemistry of ERK and CRP}

Immunohistochemistry of paraffin embedded heart and kidney tissues was performed after the tissues were fixed with 10\% formalin based on the methods described by Todorich et al. (2011) 
with slight modifications. Briefly, paraffin sections were melted at $60^{\circ} \mathrm{C}$ in the oven. Dewaxing of the samples in xylene was followed by passage through ethanol of decreasing concentration (100-80\%). Peroxidase quenching with $1 \% \mathrm{H}_{2} \mathrm{O}_{2} /$ methanol was followed by antigen retrieval performed by microwave heating in $0.01 \mathrm{M}$ citrate buffer ( $\mathrm{pH}$ 6.0) to boil. All the sections were blocked in normal goat serum $\left(10 \%\right.$, HistoMark ${ }^{\circledR}$, KPL, Gaithersburg MD, USA) and probed with anti-ERK and anti-CRP antibodies, as appropriate (Bioss, San Diego, CA, USA), 1:200 overnight at room temperature. Detection of bound antibody was carried out using biotinylated (goat anti-rabbit, $2.0 \mu \mathrm{g} / \mathrm{ml}$ ) secondary antibody and subsequently, streptavidin peroxidase (Horse Radish Peroxidase- streptavidin) according to manufacturer's protocol (HistoMark ${ }^{\circledR}$, KPL, Gaithersburg MD, USA).

The reaction product was enhanced with diaminobenzidine (DAB, Amresco ${ }^{\circledR}$, USA) for 2-3 minutes and counterstained with high definition hematoxylin (Enzo ${ }^{\circledR}$, NY - USA), with subsequent dehydration in ethanol. The slides were covered with coverslips and sealed with resinous solution. The immune-reactive positive expression of ERK- and CRP- intensive regions were viewed starting from low magnification on each slide then with $400 \times$ magnifications using a photo microscope (Olympus) and a digital camera (Toupcam ${ }^{\circledR}$, Touptek Photonics, Zhejiang, China).

\subsection{Histopathology}

Small pieces of cardiac and renal tissues were collected in $10 \%$ buffered formalin $(\mathrm{pH} 7.4)$ for proper fixation. These tissues were processed and embedded in paraffin wax. Sections of 5-6 $\mu \mathrm{m}$ in thickness were made and stained with haematoxylin and eosin for histopathological examination (Drury et al. 1976). 


\subsection{Statistical analyses}

Statistical analyses were carried out using one-way analysis of variance (ANOVA) to compare the experimental groups with Least Significant Difference (LSD) post-hoc analysis, followed by the Student's $t$-test using GraphPad Prism software (version 6.01). $P$ values $<0.05$ were considered statistically significant.

\subsection{Results}

\subsection{Effects of $\mathrm{CoCl}_{2}$ exposure and treatments with Kolaviron and Gallic acid on blood pressure parameters}

Cobalt chloride caused significant reduction $(p<0.05)$ in systolic blood pressures in the rats, compared to control. The reductions observed in diastolic and mean arterial pressures were, however, not statistically significant. Rats treated $\mathrm{CoCl}_{2}+$ Kolaviron exhibited further dosedependent reduction in systolic, diastolic and mean arterial pressures when compared with those treated with $\mathrm{CoCl}_{2}$ alone. There was also blood pressure reductions in the group exposed to $\mathrm{CoCl}_{2}+$ Gallic acid, although these were not as much as that caused by the higher dose of Kolaviron (Table 1).

\subsection{ECG waves and intervals}

Electrocardiographic measurements for control and experimental rats are presented in Table 2. No statistically significant differences were observed in the heart rate, $\mathrm{P}$ wave, PR interval, QRS duration, QT, QT corrected (Bazett) and R amplitude between rats treated with $\mathrm{CoCl}_{2}$ alone and the control rats. Similarly, rats co-treated with $\mathrm{KV}$ and GA did not show any significant alterations in most of the ECG parameters including heart rate, P wave, PR interval, QRS 
duration and $\mathrm{R}$ amplitude. The only noticeable significant $(p<0.05)$ alteration was displayed by rats co-treated with $\mathrm{CoCl} 2$ and $\mathrm{KV}(200 \mathrm{mg} / \mathrm{kg})$, which displayed prolonged QT and QTc intervals, compared to control as well as the rats given $\mathrm{CoCl}_{2}$ alone.

\subsection{Effect of KV and GA on markers of cardiac and renal injury}

In $\mathrm{CoCl}_{2}$-exposed rats, we observed significant increases $(p<0.05)$ in serum levels of all the markers of myocardial injury measured in this study: CK-MB, Lactate dehydrogenase (LDH), aspartate transaminase (AST) and xanthine oxidase (XO) (Figure 2). Kolaviron exhibited dosedependent reductions $(p<0.05)$ in all these parameters, when compared with the $\mathrm{CoCl}_{2}$ group, while Gallic acid also showed marked reduction in the activities of these enzymes. There were also significant increases $(p<0.05)$ in the markers of renal injury, urea and creatinine in the $\mathrm{CoCl}_{2}$ group compared to the control (Figure 3). The increased levels of creatinine was significantly reversed $(p<0.05)$ by both $\mathrm{KV}$ and GA, while significant $(p<0.05)$ amelioration of serum urea concentration was only obtained with $\mathrm{KV}$ at $200 \mathrm{mg} / \mathrm{kg}$.

\subsection{Effect of KV and GA on markers of oxidative stress and antioxidant defense system}

Exposure to $\mathrm{CoCl}_{2}$ caused the induction of oxidative stress in cardiac tissues, indicated by significant increases in hydrogen peroxide $\left(\mathrm{H}_{2} \mathrm{O}_{2}\right)$, malondialdehyde (MDA) and nitric oxide (NO) contents, compared to control (Table 3). Kidney tissues also showed significant elevation in MDA level. KV and GA exhibited significant antioxidant activity towards $\mathrm{H}_{2} \mathrm{O}_{2}$ in both the heart and kidneys, causing significant reduction $(p<0.05)$ in this reactive oxygen species, compared to the $\mathrm{CoCl}_{2}$ group. $\mathrm{KV}$ produced significant reduction $(p<0.05)$ of MDA levels in the kidneys, as well as significant reduction $(p<0.05)$ of NO in the heart.

From Table 4, no significant alterations were observed in the concentration of reduced glutathione (GSH) in both the heart and kidneys of rats exposed to $\mathrm{CoCl}_{2}$, with or without $\mathrm{KV}$ or 
GA. However, we observed significant reduction $(p<0.05)$ in the activities of superoxide dismutase (SOD), catalase (CAT) and glutathione S-transferase (GST) in the heart of $\mathrm{CoCl}_{2}$ treated rats, while the kidney also showed significant reductions $(p<0.05)$ in CAT and GST. KV demonstrated significant $(p<0.05)$ dose-dependent restoration of SOD, CAT and GST activities in the heart and kidneys, when compared to the $\mathrm{CoCl}_{2}$ group, while GA only exhibited significant elevation of SOD activity.

\subsection{Effect of KV and GA on myocardial and renal histoarchitecture}

Histopathological examination of the cardiac and renal tissues confirmed the biochemical findings of cardiac and renal damage due to cobalt intoxication in the rats (Figures 5 and 6). Hearts from rats that received cobalt chloride alone showed disseminated haemorrhagic lesions with congestion of coronary blood vessels and mild infiltration of the myocardium and atrium by inflammatory cells. Kidney damage was indicated histologically by severe loss of normal morphology, loss of tubular and glomerular outlines with marked peri-tubular inflammatory cell infiltration and vascular congestion. However, treatment with $\mathrm{KV}$, especially at the higher dose, and GA, prevented much of the damage as the histological appearance of the tissues tended towards that in the control rats.

\subsection{Expression of ERK and CRP in cardiac and renal tissues}

Immunohistochemically, the cardiac tissues in the control group displayed faint ERK staining [Figure 4(a)], whereas the kidneys exhibited a much greater staining intensity [Figure 4(b)]. Exposure to $\mathrm{CoCl}_{2}$ alone exhibited very weak ERK immunoreactivity in both the heart and kidneys. By contrast, rats treated with either $\mathrm{KV}$ or GA, showed a strong staining intensity for ERK in both the heart and kidneys. This effect appeared to be much stronger with KV at the higher dose. 
CRP immunoreactivity was monitored only in the heart tissues and this study [Figure 4(c)]. Rats in the $\mathrm{CoCl}_{2}$ group exhibited a strong staining intensity for CRP, compared to all other groups. The higher dose of $\mathrm{KV}$, as well as GA, both demonstrated much lower immunoreactivity for CRP, while control rats only had faint expression of this protein.

\subsection{Discussion}

The chemopreventive property of phenolic antioxidants has become very attractive in their use for protection against toxic and neoplastic effects of many xenobiotics, including heavy metals. Their ability to induce several detoxifying and antioxidant enzymes explains, in large part, the mechanisms underlying their protective actions. In this study, two natural phenolics, Kolaviron and Gallic acid have been investigated for their protective activities against cobalt toxicity in cardiac and renal tissues of Wistar rats. Cobalt, as a metal, is currently growing in importance due to recent modern applications in medical, industrial and domestic settings.

Cobalt-induced cardiac damage in the present study was indicated by significant elevation in serum CK-MB, AST and LDH activities in the group of rats treated with $\mathrm{CoCl}_{2}$ alone. Serum CK-MB, AST and LADH are well known diagnostic markers of myocardial damage. Damage to cardiomyocytes by different toxicants causes an increase in membrane permeability or rupture of the cells themselves. As a result, these enzymes, normally found intracellularly, can enter the bloodstream, thereby increasing their activities in serum (Priscilla and Prince 2009). CK-MB is highly specific as a marker of myocardial damage in this regard (Patel et al. 2010).Treatment with KV and GA effectively prevented the elevation in the activities of these enzymes. The protective effect obtained for KV was dose-dependent for all the enzymes. 
The kidney is the main site of metabolism and elimination of many metals and other toxicants (Matos et al., 2009). Toxicants which affect the kidneys can interfere with the incorporation of amino acids into proteins can increase the serum concentration of nitrogen-containing products of protein metabolism, including urea and creatinine, due to the failure of their elimination (Alessahin et al. 2005; Cuzzocrea et al. 2002). Our study revealed increased levels of urea and creatinine in the serum of $\mathrm{CoCl} 2$-treated rats, an indication of possible renal damage. Similar results were obtained by Garoui et al. (2012), who utilized the same concentration of cobalt chloride as in the present study. With respect to these renal parameters, $\mathrm{KV}$, at the higher dose, produced better amelioration of cobalt chloride-induced renal damage than GA.

We found evidence for the involvement of ROS as mediators of cardiac and renal damage in $\mathrm{CoCl}_{2}$-treated rats. There were significant increases in hydrogen peroxide levels in heart and kidneys, as well as increased malondialdehyde and nitric oxide levels, especially in cardiac tissues. This pattern of elevation of these parameters clearly indicates the induction of oxidative stress and lipid peroxidation. Increased lipid peroxidation might be responsible for increased cell membrane permeability that led to the leakage of intracellular enzymes such as CK-MB, LDH and AST into the serum. Further evidence of free radical generation was indicated by the elevated serum activity of xanthine oxidase (XO). XO is an important source of free radicals and an important marker of myocardial damage (Raghuvanshi et al. 2007). Oxidation of sulhydryl residues in xanthine dehydrogenase can easily give rise to xanthine oxidase, both enzymes being inter-convertible forms of what is collectively known as xanthine oxido-reductase (XOR) (Harrison 2002; 2004).

In ischemic/hypoxic conditions, cellular ATP is degraded to hypoxanthine which is converted by xanthine oxidase to oxygen free radicals (Hearse et al. 1986), such as superoxide radicals. XO- 
derived superoxide radicals can also react with nitric oxide forming the highly cytotoxic peroxynitrite (Trujillo et al. 1998), which causes tissue injury. In addition, cardiac damage was indicated by increased myocardial expression of $\mathrm{C}$ - reactive protein $(\mathrm{CRP})$ in $\mathrm{CoCl}_{2}$-treated rats. CRP is a prototype inflammatory marker and is used as a predictor of coronary heart disease (Calabro et al. 2012). KV and GA caused reversal of $\mathrm{CoCl}_{2}$-induced increases in oxidative stress parameters and increased CRP expression in the present study, affirming the profound antioxidant and anti-inflammatory activities of these compounds.

In order to understand the involvement of key signaling pathways in the protection of cobaltinduced injury by $\mathrm{KV}$ and/or GA, we investigated the expression of the extracellular signalregulated kinase (ERK). ERKs are one of four families of proteins called Mitogen-activated protein kinases (MAPKs) which play vital roles in signaling events involved in cell proliferation, differentiation, metabolism, survival and apoptosis. The other proteins in this class are c-Jun Nterminal kinases (JNK), p38 and ERK5 (or Big MAPK) (Rose et al. 2010). While ERKs are known to be stimulated mainly by growth factors (Ramos 2008), JNK and P38 are activated by stress factors such as UV-light, oxidant stress, infection and osmotic shock (Kyriakis and Avruch 2001), and are both collectively called Stress-activated MAPKs (SAPKs). With immunohistochemistry, both the heart and kidneys of $\mathrm{CoCl}_{2}$-treated rats consistently exhibited lower expressions of ERK. However, KV and GA produced considerably higher expressions of this protein in both the heart and kidneys.

Stimulation of the ERK pathway by various stimuli has been demonstrated by various studies to produce cardioprotection (Hausenloy and Yellon 2007). Similarly, other studies have suggested that a down-regulation of ERK 1/2 is involved in Doxorubicin-induced cardiac damage (Su et al. 2006; Xiang et al. 2009). These studies concluded that administration of substances that increase 
ERK 1/2 leads to prevention of Doxorubicin-induced cardiotoxicity. Based on these studies and the findings from our study, it is reasonable to infer that ERK activation has mechanistic implications for the protection offered by $\mathrm{KV}$ and/or GA.

The explanation for the mechanistic involvement of ERKs, as observed in the present study, may be linked to their ability to directly phosphorylate Nrf-2, causing the stimulation of the transcription factor. Downstream effectors of Nrf-2 include phase II detoxifying enzymes, such as GSTs, as well as antioxidant enzymes like SOD, CAT and GPx. We found significantly elevated activities of SOD, CAT and GST in the cardiac and renal tissues of rats treated with KV and GA, compared to those treated with $\mathrm{CoCl}_{2}$ alone. This points to a likely up-regulation of these enzymes by mechanisms possibly related to the activation of ERK, as observed in this study.

The data on blood pressure indicated a reduction in blood pressure indices and especially the systolic blood pressure, in rats treated with cobalt chloride alone. This is in agreement with previous reports that infusion of $\mathrm{Co}^{2+}(55 \mathrm{mg} / \mathrm{kg})$ lowered blood pressure in Wistar rats by decreasing total peripheral resistance, suggesting that cobalt acted by vasodilator effects on blood vessels (Dugin et al. 1991). With rats co-treated with Kolaviron or Gallic acid, we observed further decreases in all blood pressure indices measured, suggesting that these compounds exerted synergistic effects with cobalt chloride to cause hypotension in the rats. Previous reports have identified lowering effects of Garcinia kola extracts on systolic and mean arterial blood pressures (Naiho and Ugwu 2009). Like cobalt, the blood pressure-lowering effect of Garcinia kola extracts was attributed to its relaxant effects on vascular smooth muscles. Substances that cause vasorelaxation could act by stimulating cyclic AMP which, by an energyrequiring $\mathrm{Ca}^{2+}$-binding mechanism, may produce a decrease in sarcoplasmic $\mathrm{Ca}^{2+}$ and hence, 
relaxation. Juxtaposing our findings in the present study with those of Naiho and Ugwu (2009), it may be reasonable to suggest that the hypotension-inducing factor in Garcinia kola may, indeed be Kolaviron. To support this assertion, previous experiments in rat superior mesenteric arteries have provided functional evidence that Kolaviron produce vaso-relaxant effects by blockade of influx of extracellular $\mathrm{Ca}^{2+}$, inhibition of intracellular $\mathrm{Ca}^{2+}$ release and opening of $\mathrm{K}^{+}$channels (Adaramoye and Medeiros 2009).

Electrocardiography is considered one of the most important clinical tests for diagnosis of cardiac dysfunction (Patel et al. 2010). ECG assessments in this study showed that rats treated with $\mathrm{CoCl}_{2}$ alone did not show any statistically significant differences in the patterns of most ECG parameters, when compared to control rats. However, co-treatment of $\mathrm{CoCl}_{2}$ with $\mathrm{KV}$ at $200 \mathrm{mg} / \mathrm{kg}$ produced a noticeable alteration in the form of prolonged QT and QTc intervals, compared to control. The QT interval is the time from the start of the QRS complex to the end of the $\mathrm{T}$ wave. QT is a measure of the time required for the rapid inflow of $\mathrm{Na}^{+}$and $\mathrm{Ca}^{2+}$, resulting in the depolarization of the myocardium and the outflow of $\mathrm{K}^{+}$, ultimately resulting in repolarization (Moskovitz et al. 2013). Since the rate of depolarization and repolarization depends on a patient's heart rate, QT is usually corrected to the QTc value. Prolonged QT/QTc interval indicates delayed repolarization of the heart, and usually identifies patients with increased risk of acute cardiovascular complications including ventricular dysrhythmias, seizurelike activities or sudden cardiac death (Witchel et al. 2000). Our finding from the present study would suggest that KV at high doses may predispose to cardiovascular risks and must, therefore, be used with caution.

Histopathological findings of rats treated with Kolaviron and gallic acid showed a near normal morphology of the heart and kidney tissues, compared to those of rats treated with $\mathrm{CoCl}_{2}$ alone, 
which showed disseminated hemorrhagic lesions in the myocardium and inflammatory cell infiltration and vascular congestion in the kidneys.

Overall, our study clearly shows the cardio-protective and nephro-protective effects of Kolaviron and Gallic acid against tissue damage induced by cobalt chloride. Our findings lend further credence to previous reports on the health benefits of these compounds on the heart and kidneys, as have been reported elsewhere (Adaramoye and Lawal 2015; Adedara et al. 2015; Priscilla and Prince 2009). Significant correlation in ERK expression and the activities of antioxidant and detoxifying enzymes in this study provided some mechanistic insight into the protective abilities of these compounds. However, the use of Kolaviron in treating conditions involving oxidative stress must be with caution to avoid synergistic drug-drug interactions that may potentiates its effects on lowering of blood pressure, as well as the risk of cardiovascular complications associated with the use of high doses.

\section{Conflict of interest}

The authors declare that they have no conflict of interest 


\section{References}

Adaramoye, O.A., and Lawal, S.O. 2015. Kolaviron, a biflavonoid fraction from Garcinia kola, protects against isoproterenol-induced injury by mitigating cardiac dysfunction and oxidative stress in rats. J. Basic Clin. Physiol. Pharmacol. 26: 65-72.

Adaramoye, O.A., and Medeiros, I.A. 2009. Endothelium-independent vasodilation induced by Kolaviron, a biflavonoid complex from Garcinia kola seeds, in rat superior mesenteric arteries. J. Smooth Muscle Res. 45: 39-53

Adedara, I.A., Daramola, Y.M., Dagunduro, J.O., Aiyegbusi, M.A., and Farombi, E.O. 2015. Renoprotection of Kolaviron against benzo (A) pyrene-induced renal toxicity in rats. Ren. Fail. 37: 497-504

Adedara, I.A., and Farombi, E.O. 2012. Chemoprotection of Ethylene glycol monoethyl etherinduced reproductive toxicity in male rats by kolaviron, isolated biflavonoid from Garcinia kola seed, Hum. Exp. Toxicol. 31: 506-517.

Ahmed, M., and Siddiqui, M.K.J. 2007. Low level lead exposure and oxidative stress current opinion. Clin. Chim. Acta, 383: 57-64.

Akaike, T., Ando, M., Oda, T., Doi, T., Ijiri, S., Araki, S., and Maeda, H. 1990. Dependence on O2- generation by xanthine oxidase of pathogenesis of influenza virus infection in mice. J. Clin. Invest. 85: 739-745. 
Atessahin, A., Yilmaz, S., Karahan, I., Ceribasi, A.O., and Karaoglu, A. 2005. Effects of lycopene against cisplatin-induced nephrotoxicity and oxidative stress in rats. Toxicology, 212: 116-23.

Baird, L., and Dinkova-Kostova, A.T. 2011. The cytoprotective role of the Keap1-Nrf2 pathway. Arch. Toxicol. 85: 241-272.

Banza, C.L.N., Nawrot, T.S., Haufroid, V., Decre'e, S., DePutter, T. et al. 2009. High human exposure to cobalt and other metals in Katanga, a mining area of the Democratic Republic of Congo. Environ. Res. 109: 745-752

Barceloux, D. 1999. Cobalt. Clin. Toxicol. 37: 201-16.

Calabro, P., Golia, E., and Yeh, E.T. 2012. Role of C-reactive protein in acute myocardial infarction and stroke: possible therapeutic approaches. Curr. Pharm. Biotechnol. 100: 23-28

Catelas, I., Petit, A., Vali, H., Fragiskatos, C., Meilleur, R., et al. 2005. Quantitative analysis of macrophage apoptosis vs. necrosis induced by cobalt and chromium ions in vitro. Biomaterials, 26: $2441-2453$.

Cheyns, K., Nkulu, B.L., Ngombe, L.K., Asosa, J.N., and Haufroid, V. 2014. Pathways of human exposure to cobalt in Katanga, a mining area of the D.R. Congo. Sci. Total Environ. 490: 313321.

Cuzzocrea, S., Mazzon, E., Dugo, L., Serraino, I., Di Paola R. et al. 2002. A role of superoxide in gentamicin-mediated nephropathy in rats. Eur. J. Pharmacol. 16: 67-76. 
Drury, R.A., Wallington, E.A., and Cancerson R. 1976. Carlton's Histopathological Techniques, fourth ed. Oxford University Press, Oxford, London, New York.

Dugin, S.F., Zakharova, N.V., and Medvedev, O.S. 1991. Hemodynamic mechanisms of the hypotensive effect of cobalt in anesthesized rats. Kardiologiia, 31 (6): 80-82

Farombi, E.O., Adedara, I.A., Akinrinde, S.A., Ojo, O.O., and Eboh, A.S. 2012. Protective effects of kolaviron and quercetin on cadmium-induced testicular damage and endocrine pathology in rats. Andrologia, 44: 273-284.

Franco, R., Sanchez-Olea, R., Reyes-Reyes, E.M., and Panayoitidis, M.I. 2009. Environmental toxicity, oxidative stress and apoptosis. Mutation Res. 674: 3-22.

Garoui, E.M., Fetoui, H., Makni, F.A., Boudawara, T., and Zeghal N. 2011. Cobalt chloride induces hepatotoxicity in adult rats and their suckling pups, Exp. Toxicol. Pathol. 63: 9-15.

Garoui, E.M., Troudi, A., Fetoui, H., Soudani, N., Boudawara, T., et al. 2012. Propolis attenuates cobalt-induced nephrotoxicity in adult rats and their progeny. Exp. Toxicol. Pathol. 64: 837-846.

Gornal, A.G., Bardawill, J.C., and David, M.M. 1949. Determination of serum proteins by means of Biuret reaction. J Biol. Chem. 177: 751-766. 
Haagenson, K.K., and Wu, G.S. 2010. The role of MAPkinases and MAP kinase phosphatase-1 in resistance to breast cancer treatment. Cancer Met. Rev. 29: 143-149.

Habig, W.H., Pabst, M.J., and Jacoby, W.B. 1974. Glutathione-S-transferase Activity: The Enzymic step in Mercapturic Acid formation. J. Biol. Chem. 249: 130-139.

Harrison, R. 2002. Structure and function of xanthine oxido-reductase; where are we now? Free Radic. Biol. Med. 33: 774-797

Harrison, R. 2004. Physiological roles of xanthine oxidoreductase. Drug Metab. Rev. 36: 363375

Hasegawa, M., Yoshida, K., Wakabayashi, H. et al. 2012. Cobalt and chromium ion release after large-diameter metal-on-metal total hip arthroplasty. J. Arthroplasty, 27: 990-6.

Hausenloy, D., and Yellon D. 2007. Reperfusion injury salvage kinase signaling: taking a RISK for cardio-protection. Heart Fail. Rev. 12: 217-34

Hearse, D.J., Manning, A.S., Downey, J.M., and Yellon, D.M. 1986. Xanthine oxidase: a critical mediator of myocardial injury during ischemia and reperfusion? Acta Physiol. Scand. Suppl. 548: $65-78$.

Havsteen, B.H. 2002. The biochemistry and medical significance of the flavonoids. Pharmacol. Ther. 96: 67-202. 
Hormann, V., Kumi-Diaka, J., Durity, M., and Rathinavelu, A. 2012. Anticancer activities of genistein- topotecan combination in prostate cancer cells. J. Cell Mol. Med. 16: 2631-2636.

Itoh, K., Tong, K.I., and Yamamoto, M. 2004. Molecular mechanism activation of Nrf2-Keap1 pathway in regulation of adaptive response to electrophiles. Free Radic. Biol. Med. 36: 12081213

Iwu, M.M. 1985. Antihepatotoxic constituents of Garcinia kola seeds. Experientia, 41: 699-700

Jelkmann, W., and Lundby, C. 2011. Blood doping and its detection. Blood, 118: 2395-404.

Jollow, D.J., Mitchell, J.R., Zampaglione, N., and Gillette, J.R. 1994. Bromobenzene-Induced Liver Necrosis; Protective Role of glutathione \& Evidence for 3, 4 Bromobenzene Oxide as the Hepatotoxic Metabolite. Pharmacology, 11 (3): 151- 169.

Kim, D.O., Lee, K.W., Lee, H.J., and Lee, C.Y. 2002. Vitamin C equivalent antioxidant capacity of phenolic phytochemicals, J. Agric. Food Chem. 50: 3713-3717.

Kim, J., and Jang, H. 2014. Nrf2-Mediated HO-1 Induction Coupled with the ERK Signaling Pathway Contributes to Indirect Antioxidant Capacity of Caffeic Acid Phenethyl Ester in HepG2 Cells. Int. J. Mol. Sci. 15: 12149-12165.

Kroes, B.H., van den Berg, A.J., Quarles van Ufford, H.C., van Dijk, H., and Labadie, R.P.1992. Anti-inflammatory activity of gallic acid, Planta Med. 58: 499-504. 
Kubrak, O.I., Husak, V.V., Rovenka, B.M., Storey, J.M., Storey, K.S., et al. 2011. Cobaltinduced oxidative stress in brain, liver and kidney of goldfish Carassius auratus. Chemosphere, 856: 983-989.

Kyriakis, J.M., and Avruch, J. 2001. Mammalian mitogen-activated protein kinase signal transduction pathways activated by stress and inflammation. Physiol. Rev. 81: 807-869.

Lippi, G., Franchini, M., and Guidi, G.C. 2006. Blood doping by cobalt. Should we measure cobalt in athletes? J. Occup. Med. Toxicol. 1: e1-e3.

Ma, J., Luo, X.D., Protiva, P., Yang, H., Ma, C., et al. 2003. Bioactive novel polyphenols from the fruit of Manilkara zapota (Sapodilla), J. Nat. Prod. 7: 983-986.

Macnair, R.D., Wynn-Jones, H., Wimhurst, J.A., Toms, A., and Cahir, J. 2012. Metal ion levels not sufficient as a screening measure for adverse reactions in metal-on-metal hip arthroplasties. J. Arthroplasty, 28: 78-83.

Mann, G.E., Bonacasa, B., Ishii, T., and Siow, R.C. 2009. Targeting the redox sensitive Nrf2Keap1 defense pathway in cardiovascular disease: protection afforded by dietary isoflavones. Curr. Opin. Pharmacol. 9: 139-145

Matos, R.C., Vieira, C., Morais, S., Pereira, M.L., and De Jesus, J.P. 2009. Nephrotoxicity of CCA-treated wood: a comparative study with $\mathrm{As}_{2} \mathrm{O}_{5}$ and $\mathrm{CrO} 3$ on mice. Environ. Toxicol. Pharmacol. 27: 259-63. 
Misra, H.P., and Fridovich, I. 1972. The role of superoxide anion in the auto-oxidation of epinephrine and a simple assay for superoxide dismutase. J. Biol. Chem. 247: 3170-3175.

Mobasheri, A., and Proudman, C.J. 2015. Cobalt chloride doping in racehorses: Concerns over a potentially lethal practice. Vet. J. 205: $335-338$

Moskovitz, J.B., Hayes, $\quad$ B.D., Martinez, J.P., Mattu, A., and Brady, W.J. 2013. Electrocardiographic implications of the prolonged QT interval. Am. J. Emerg. Med. 31: 866-71.

Naiho, A.O., and Ugwu, A.C. 2009. Blood pressure reducing effect of bitter kola (Garcinia kola, Heckel) in Wistar rats. Afr. J. Biomed. Res. 12: 131-134.

Olaleye, S.B., Farombi, E.O., Adewoye, E.A., Owoyele, B.V., Onasanwo, S.A. et al. 2000. Analgesic and anti-inflammatory effects of kolaviron (a Garcinia kola seed extract). Afr. J. Biomed. Res. 3: 171-174.

Olaleye, S.B., Adaramoye, O.A., Erigbali, P.P., and Adeniyi, O.S. 2007. Lead exposure increases oxidative stress in the gastric mucosa of $\mathrm{HCl} /$ ethanol-exposed rats. World J. Gastroenterol. 13: $5121-5126$

Oyagbemi, A.A., Omobowale, T.O., Akinrinde, A.S., Saba, A.B., Ogunpolu, .B.S., et al. 2015. Lack of reversal of oxidative damage in renal tissues of lead acetate-treated rats. Environ. Toxicol. 30: 1235-1243. 
Park, J.H., Lee, J.K., Kim, H.S., Chung, S.T., Eom, J.H., et al. 2004. Immunomodulatory effect of caffeic acid phenethyl ester in Balb/c mice. Int. Immunopharmacol. 4: 429-436.

Patel, V., Upaganlawar, A., Zalawadia, R., and Balaraman, R. 2010. Cardioprotective effect of melatonin against isoproterenol induced myocardial infarction in rats: a biochemical, electrocardiographic and histoarchitectural evaluation. Eur. J. Pharmacol. 644: 160-168.

Paustenbach, D.J., Tvermoes, B.E., Unice, K.M., Finley, B.L., and Kerger, B.D. 2013. A review of the health hazards posed by cobalt. Crit. Rev. Toxicol. 43: 316-362

PHS (PUBLIC HEALTH SERVICE). 1996. Public Health Service Policy on Humane Care and the Use of Laboratory Animals. US Department of Health and Humane Services, Washington, DC, pp. 99-158.

Priscilla, H.D., and Prince, P.S.M. 2009. Cardioprotective effect of Gallic acid on cardiac troponin-T, cardiac marker enzymes, lipid peroxidation products and antioxidants in experimentally induced myocardial infarction in Wistar rats. Chem. Biol. Interact. 179: 118-124

Raghuvanshi, R., Kaul, A., Bhakuni, P., Mishra, A., and Misra, M.K. 2007. Xanthine oxidase as a marker of myocardial infarction and cardioprotection. Heart Fail. Rev. 12: 217-234.

Ramos, J.W. 2008. The regulation of extracellular signal-regulated kinase (ERK) in mammalian cells. Int. J. Biochem. Cell Biol. 40: 2707-2719. 
Rose, B.A., Force, T., and Wang, Y. 2010. Mitogen-activated protein kinase signaling in the heart: Angels versus demons in a heart-breaking tale. Physiol. Rev. 90

Singh, J., Rai, G.K., Upadhyay, A.K., Kumar, R., and Singh, K.P. 2004. Antioxidant phytochemicals in tomato (Lycopersicon esculentum) Ind. J. Agric. Sci. 74: 3-5.

Sinha, K.A. 1971. Colorimetric assay of catalase. Anal. Biochem. 47: 389-94.

Son, Y., Cheng, Y.K., Kim, N., Chung, H., Kang, D.G., et al. 2011. Mitogen-activated protein kinases and reactive oxygen species: How can ROS activate MAPK pathways? Journal of Signal Transduction, 2011: 792639 Doi:10.1155/2011/792639

Su, H.F., Samsamshariat, A., Fu, J., Shan, Y.X., Chen, Y.H., et al. 2006. Oleylethanolamide activates Ras-Erk pathway and improves myocardial function in doxorubicin-induced heart failure. Endocrinol. 147: 827-834.

Todorich, B., Olopade, J.O., Surguladze, N., Zhang, X., Neely, E., et al. 2011. The mechanism of vanadium-mediated developmental hypomyelination is related to destruction of oligodendrocyte progeinitors through a relationship with ferritin and iron. Neurotox. Res. 19: 361-373.

Trujillo, M., Alvarez, M.N., Peluffo, G., Freeman, B.A., and Radi, R. 1998. Xanthine-oxidasemediated decomposition of S-nitrosothiols. J. Biol. Chem. 273: 7828-7834. 
Tvermoes, B.E., Finley, B.L., Unice, K.M., Otani, J.M., Paustenbach, D.J., and Galbraith, D.A. 2013. Cobalt whole blood concentrations in healthy adult male volunteers following two weeks of ingesting cobalt supplement. Food Chem. Toxicol. 53: 417-24.

Varshney, R., and Kale, R.K. 1990. Effect of calmodulin antagonists on radiation induced lipidmperoxidation in microsomes. Int. J. Biol. 158: 733-741.

Witchel, H.J., and Hancox, J.C. 2000. Familial and acquired long QT syndrome and the cardiac rapid delayed rectifier potassium current. Clin. Exp. Pharmacol. Physiol. 27: 753-66.

Wolff, S.P. 1994. Ferrous ion oxidation in the presence of ferric ion indicator xylenol orange for measurement of hydroperoxides. Methods Enzymol. 233: 182-189.

Xiang, P., Deng, H., Li, K., Huang, G., Chen, Y., et al., et al. 2009. Dexrazoxane protects against doxorubicin-induced cardiomyopathy: up-regulation of Akt and Erk phosphorylation in a rat model. Cancer Chemother. Pharmacol. 63: 343-349. 


\section{Legends to Figures}

Figure 1: Structures of a) Kolaviron and b) Gallic acid

Figure 2: Effect of cobalt chloride with or without Kolaviron or Gallic acid on cardiac marker enzymes

Values are presented as mean \pm standard deviation $(n=10)$.

a represents significant difference at $p<0.05$, when compared with control; ${ }^{b}$ represents significant difference at $p<0.05$, when compared with $\mathrm{CoCl}_{2}$ group

Figure 3: Effect of cobalt chloride with or without Kolaviron or Gallic acid on serum urea and creatinine

Values are presented as mean \pm standard deviation $(n=10)$.

a represents significant difference at $p<0.05$, when compared with control; ${ }^{b}$ represents significant difference at $p<0.05$, when compared with $\mathrm{CoCl}_{2}$ group

Figure 4: Immunohistochemical staining patterns of a.) ERK in cardiac tissues; b.) ERK in kidney tissues, and c.) CRP in cardiac tissues, of rats exposed to cobalt chloride with or without treatment with Kolaviron and Gallic acid.

$\mathrm{A}=$ Control; $\mathrm{B}=\mathrm{CoCl}_{2}$ alone; $\mathrm{C}=\mathrm{CoCl}_{2}+\mathrm{KV}(100 \mathrm{mg} / \mathrm{kg}) ; \mathrm{D}=\mathrm{CoCl}_{2}+\mathrm{KV}(200 \mathrm{mg} / \mathrm{kg})$; $\mathrm{E}=\mathrm{CoCl}_{2}+$ Gallic acid $(120 \mathrm{mg} / \mathrm{kg})$. Intensity of staining is indicated with black arrows

Figure 5: Photomicrographs of heart sections of rats exposed to cobalt chloride with or without treatment with Kolaviron and Gallic acid.

$\mathrm{A}=$ Control; $\mathrm{B}=\mathrm{CoCl}_{2}$ alone; $\mathrm{C}=\mathrm{CoCl}_{2}+\mathrm{KV}(100 \mathrm{mg} / \mathrm{kg}) ; \mathrm{D}=\mathrm{CoCl}_{2}+\mathrm{KV}(200 \mathrm{mg} / \mathrm{kg})$; $\mathrm{E}=\mathrm{CoCl}_{2}+$ Gallic acid $(120 \mathrm{mg} / \mathrm{kg})$. Hemorrhagic lesions in the myocardium are indicated with blue arrows. 
Figure 6: Photomicrographs of kidney sections of rats exposed to cobalt chloride with or without treatment with Kolaviron and Gallic acid.

$\mathrm{A}=$ Control; $\mathrm{B}=\mathrm{CoCl}_{2}$ alone; $\mathrm{C}=\mathrm{CoCl}_{2}+\mathrm{KV}(100 \mathrm{mg} / \mathrm{kg}) ; \mathrm{D}=\mathrm{CoCl}_{2}+\mathrm{KV}(200 \mathrm{mg} / \mathrm{kg})$; $\mathrm{E}=\mathrm{CoCl}_{2}+$ Gallic acid $(120 \mathrm{mg} / \mathrm{kg})$. Hemorrhagic lesions and congested vessels are indicated with blue arrows; black arrows show severe inflammatory cell infiltration. 
Table 1: Effects of Kolaviron and Gallic acid on blood pressure parameters rats exposed to Cobalt chloride
A
B
C
D
$\mathbf{E}$

Systolic blood
pressure
(mmHg)

$136.10 \pm 1.89^{\mathbf{a}} \quad 129.25 \pm 0.55^{\mathbf{a}, \mathbf{b}} \quad 93.95 \pm 17.81^{\mathbf{a}, \mathbf{b}} \quad 117.29 \pm 4.53^{\mathbf{a}, \mathbf{b}}$

$154.56 \pm 5.04$

$136.10 \pm 1.89$

$129.25 \pm 0.55$

$93.95 \pm 17.8$

Diastolic blood

$125.00 \pm 6.36$

$117.55 \pm 11.86$

$114.08 \pm 5.05$

$82.60 \pm 17.94^{\mathbf{a}, \mathbf{b}} \quad 94.50 \pm 17.30^{\mathbf{a}}$

(mmHg)

Mean arterial

$134.44 \pm 5.92$

$123.41 \pm 8.05$

$118.92 \pm 3.50$

$85.98 \pm 17.94^{\mathbf{a}, \mathbf{b}}$

$101.76 \pm 12.90^{\mathbf{a}, \mathbf{b}}$

blood pressure

(mmHg)

\footnotetext{
Values are presented as mean \pm standard deviation $(n=10)$. $\mathrm{A}=\mathrm{Control} ; \mathrm{B}=\mathrm{CoCl}_{2}$ alone; $\mathrm{C}=\mathrm{CoCl}_{2}+\mathrm{KV}$ $(100 \mathrm{mg} / \mathrm{kg}) ; \mathrm{D}=\mathrm{CoCl}_{2}+\mathrm{KV}(200 \mathrm{mg} / \mathrm{kg}) ; \mathrm{E}=\mathrm{CoCl}_{2}+$ Gallic acid $(120 \mathrm{mg} / \mathrm{kg})$. ${ }^{\text {a }}$ represents significant difference at $p<0.05$, when compared with control; ${ }^{\mathrm{b}}$ represents significant difference at $p<0.05$, when compared with $\mathrm{CoCl}_{2}$ group
} 
Table 2: Effect of Kolaviron and Gallic acid on electrocardiographic parameters in rats exposed to cobalt chloride

\begin{tabular}{|c|c|c|c|c|c|}
\hline & $\mathbf{A}$ & B & $\mathbf{C}$ & D & $\mathbf{E}$ \\
\hline $\begin{array}{l}\text { Heart rate } \\
\text { (/min) }\end{array}$ & $278.00 \pm 20.42$ & $291.33 \pm 38.42$ & $274.33 \pm 19.40$ & $282.00 \pm 49.50$ & $303.50 \pm 38.89$ \\
\hline $\begin{array}{l}\text { P wave } \\
\text { duration } \\
\text { (milliseconds) }\end{array}$ & $21.67 \pm 1.53$ & $20.00 \pm 7.81$ & $23.67 \pm 3.06$ & $17.50 \pm 4.95$ & $21.50 \pm 12.02$ \\
\hline $\begin{array}{l}\text { PR interval } \\
\text { (milliseconds) }\end{array}$ & $41.00 \pm 1.00$ & $40.33 \pm 4.62$ & $47.67 \pm 7.51$ & $38.00 \pm 4.24$ & $36.50 \pm 9.19$ \\
\hline $\begin{array}{l}\text { QRS duration } \\
\text { (milliseconds) }\end{array}$ & $16.67 \pm 1.53$ & $19.00 \pm 5.29$ & $19.33 \pm 4.16$ & $21.00 \pm 5.66$ & $14.50 \pm 9.19$ \\
\hline $\begin{array}{l}\text { QT segment } \\
\text { (milliseconds) }\end{array}$ & $78.67 \pm 9.02$ & $76.33 \pm 8.51$ & $69.33 \pm 1.16$ & $99.50 \pm 9.19^{\mathbf{a}, \mathbf{b}}$ & $71.00 \pm 5.66$ \\
\hline $\begin{array}{l}\text { QT corrected } \\
\text { Bazett } \\
\text { (milliseconds) }\end{array}$ & $168.33 \pm 16.44$ & $167.00 \pm 10.44$ & $147.67 \pm 5.03$ & $214.00 \pm 1.41^{\mathbf{a , b}}$ & $159.50 \pm 23.34$ \\
\hline $\begin{array}{l}\text { R amplitude } \\
\text { (milliseconds) }\end{array}$ & $0.24 \pm 0.036$ & $0.22 \pm 0.056$ & $0.29 \pm 0.035$ & $0.31 \pm 0.129$ & $0.21 \pm 0.066$ \\
\hline $\begin{array}{l}\text { Values are preser } \\
(100 \mathrm{mg} / \mathrm{kg}) ; \mathrm{D}= \\
\text { difference at } p< \\
\text { compared with } \mathrm{C}\end{array}$ & $\begin{array}{l}\text { d as mean } \pm \text { stan } \\
\mathrm{oCl}_{2}+\mathrm{KV}(200 \\
05, \text { when comp } \\
\mathrm{l}_{2} \text { group }\end{array}$ & Ird devia & 10). $A=C$ & $\mathrm{~B}=\mathrm{CoCl}_{2}$ alone; & $\begin{array}{l}=\mathrm{CoCl}_{2}+\mathrm{KV} \\
\text { sents significant } \\
p<0.05 \text {, when }\end{array}$ \\
\hline
\end{tabular}


Table 3: Effects of Kolaviron and Gallic acid on markers of oxidative stress in cardiac and renal tissues of rats exposed to Cobalt chloride

\begin{tabular}{|c|c|c|c|c|c|c|}
\hline & & $\mathbf{A}$ & B & $\mathbf{C}$ & D & $\mathbf{E}$ \\
\hline \multirow{3}{*}{$\begin{array}{l}\text { Hydrogen } \\
\text { peroxide } \\
\text { (micromole/min/mg } \\
\text { protein) }\end{array}$} & Heart & $10.95 \pm 0.46$ & $12.08 \pm 0.74^{\mathbf{a}}$ & $11.33 \pm 0.35^{\mathbf{b}}$ & $10.87 \pm 0.50^{\mathbf{b}}$ & $10.77 \pm 0.70^{\mathbf{b}}$ \\
\hline & & & & & & \\
\hline & Kidney & $10.31 \pm 0.27$ & $11.17 \pm 0.50^{\mathbf{a}}$ & $9.86 \pm 0.40^{\mathbf{b}}$ & $9.83 \pm 0.61^{\mathbf{b}}$ & $10.15 \pm 0.26^{\mathbf{b}}$ \\
\hline \multirow[t]{2}{*}{$\underset{\text { (micromole/g tissue) }}{\text { Malondialdehyde }}$} & Heart & $0.63 \pm 0.04$ & $0.91 \pm 0.17^{\mathbf{a}}$ & $0.90 \pm 0.11$ & $0.89 \pm 0.04$ & $0.90 \pm 0.10$ \\
\hline & Kidney & $1.40 \pm 0.47$ & $1.64 \pm 0.08$ & $1.10 \pm 0.19^{\mathbf{b}}$ & $1.02 \pm 0.04^{\mathbf{b}}$ & $1.16 \pm 0.30$ \\
\hline \multirow[t]{2}{*}{$\begin{array}{l}\text { Nitric oxide } \\
\text { (micromole/litre) }\end{array}$} & Heart & $0.14 \pm 0.03$ & $0.19 \pm 0.01^{\mathbf{a}}$ & $0.19 \pm 0.05$ & $0.16 \pm 0.02^{\mathbf{b}}$ & $0.14 \pm 0.03^{\mathbf{b}}$ \\
\hline & Kidney & $0.75 \pm 0.10$ & $0.76 \pm 0.13$ & $0.69 \pm 0.16$ & $0.65 \pm 0.09$ & $0.67 \pm 0.13$ \\
\hline
\end{tabular}

Values are presented as mean \pm standard deviation $(n=10)$. $\mathrm{A}=$ Control; $\mathrm{B}=\mathrm{CoCl}_{2}$ alone; $\mathrm{C}=\mathrm{CoCl}_{\mathbf{2}}+\mathrm{KV}$

$(100 \mathrm{mg} / \mathrm{kg}) ; \mathrm{D}=\mathrm{CoCl}_{2}+\mathrm{KV}(200 \mathrm{mg} / \mathrm{kg}) ; \mathrm{E}=\mathrm{CoCl}_{2}+$ Gallic acid $(120 \mathrm{mg} / \mathrm{kg})$

${ }^{a}$ represents significant difference at $p<0.05$, when compared with control; ${ }^{b}$ represents significant difference at $p<0.05$, when compared with $\mathrm{CoCl}_{2}$ group 
Table 4: Effects of Kolaviron and Gallic acid on antioxidant systems in cardiac and renal tissues of rats exposed to Cobalt chloride

\begin{tabular}{|c|c|c|c|c|c|c|}
\hline & & $\mathbf{A}$ & B & $\mathbf{C}$ & D & $\mathbf{E}$ \\
\hline \multirow{2}{*}{$\begin{array}{l}\text { GSH } \\
\text { (micromole/g } \\
\text { tissue) }\end{array}$} & Heart & $43.80 \pm 1.07$ & $43.90 \pm 0.37$ & $44.18 \pm 0.53$ & $43.95 \pm 0.51$ & $44.50 \pm 0.61$ \\
\hline & Kidney & $47.57 \pm 0.47$ & $47.20 \pm 0.71$ & $47.02 \pm 0.63$ & $46.54 \pm 0.66$ & $47.48 \pm 1.53$ \\
\hline \multirow{2}{*}{$\begin{array}{l}\text { SOD } \\
\text { (units/ mg } \\
\text { protein) }\end{array}$} & Heart & $0.19 \pm 0.07$ & $0.018 \pm 0.007^{\mathbf{a}}$ & $0.21 \pm 0.07^{\mathbf{b}}$ & $0.24 \pm 0.03^{\mathbf{b}}$ & $0.25 \pm 0.06^{\mathbf{b}}$ \\
\hline & Kidney & $0.085 \pm 0.022$ & $0.083 \pm 0.026$ & $0.184 \pm 0.047^{\mathbf{b}}$ & $0.265 \pm 0.034^{\mathbf{b}}$ & $0.264 \pm 0.066^{\mathbf{b}}$ \\
\hline \multirow{2}{*}{$\begin{array}{l}\text { CAT } \\
\text { (micromole } \mathrm{H}_{2} \mathrm{O} \\
\text { consumed } / \mathbf{m i n}_{2} / \mathrm{mg} \\
\text { protein) }\end{array}$} & Heart & $31.57 \pm 1.36$ & $26.95 \pm 1.42^{\mathbf{a}}$ & $31.78 \pm 0.97^{\mathbf{b}}$ & $31.50 \pm 1.31^{\mathbf{b}}$ & $27.90 \pm 1.45$ \\
\hline & Kidney & $89.33 \pm 4.10$ & $79.69 \pm 2.38^{\mathbf{a}}$ & $79.18 \pm 7.01$ & $78.86 \pm 5.11$ & $77.16 \pm 4.70$ \\
\hline $\begin{array}{l}\text { GST } \\
\text { (mmole CDNB- }\end{array}$ & Heart & $0.021 \pm 0.004$ & $0.011 \pm 0.006^{\mathbf{a}}$ & $0.021 \pm 0.006^{\mathbf{b}}$ & $0.023 \pm 0.009^{\mathbf{b}}$ & $0.018 \pm 0.003$ \\
\hline GSH complex & & & & & & \\
\hline $\begin{array}{l}\text { formed } / \mathrm{min} / \mathrm{mg} \\
\text { protein) }\end{array}$ & Kidney & $0.014 \pm 0.005$ & $0.0021 \pm 0.0009^{\mathbf{a}}$ & $0.0065 \pm 0.0014^{\mathbf{b}}$ & $0.0078 \pm 0.0045^{\mathbf{b}}$ & $0.0076 \pm 0.004$ \\
\hline
\end{tabular}

Values are presented as mean \pm standard deviation $(n=10)$. $\mathrm{A}=$ Control; $\mathrm{B}=\mathrm{CoCl}_{2}$ alone; $\mathrm{C}=\mathrm{CoCl}_{\mathbf{2}}+\mathrm{KV}$ $(100 \mathrm{mg} / \mathrm{kg}) ; \mathrm{D}=\mathrm{CoCl}_{2}+\mathrm{KV}(200 \mathrm{mg} / \mathrm{kg}) ; \mathrm{E}=\mathrm{CoCl}_{2}+$ Gallic acid $(120 \mathrm{mg} / \mathrm{kg})$

${ }^{a}$ represents significant difference at $p<0.05$, when compared with control; ${ }^{b}$ represents significant difference at $p<0.05$, when compared with $\mathrm{CoCl}_{2}$ group 


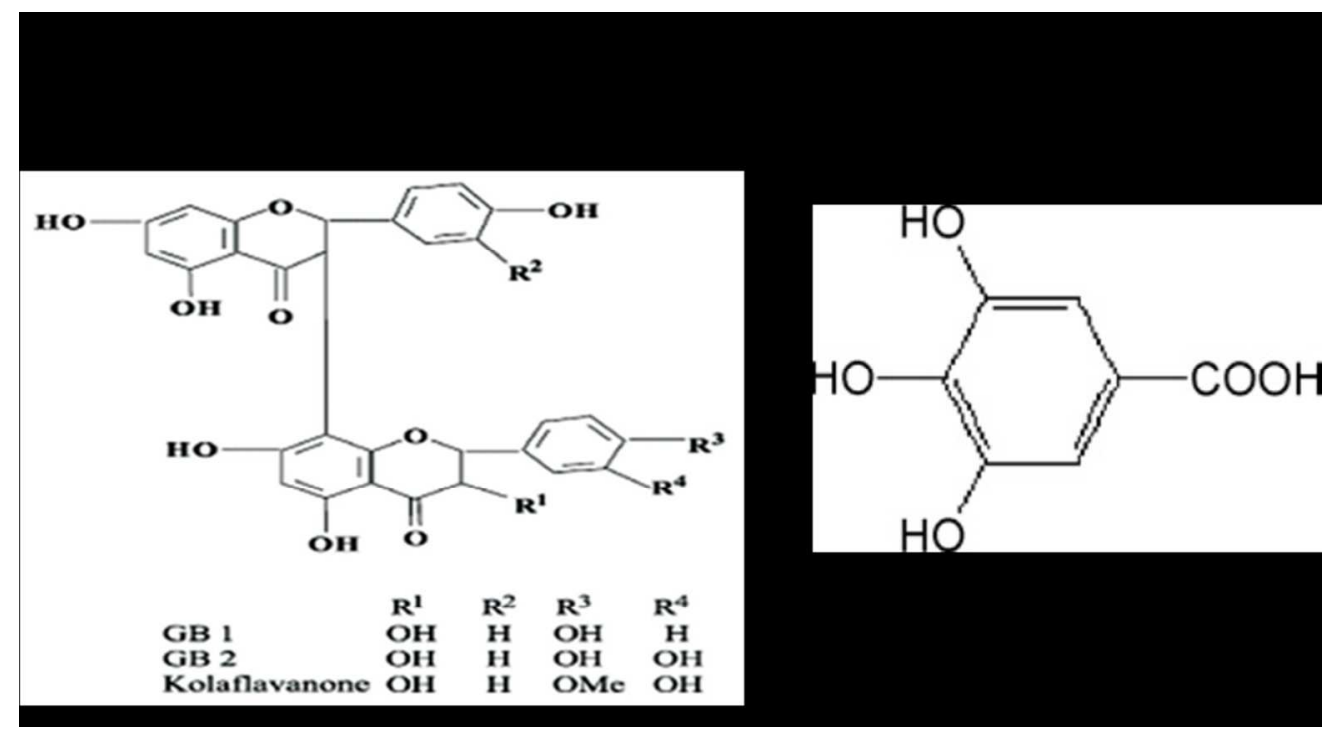

Figure 1: Structures of a) Kolaviron and b) Gallic acid $82 \times 45 \mathrm{~mm}(300 \times 300$ DPI $)$ 


$$
\text { a }
$$

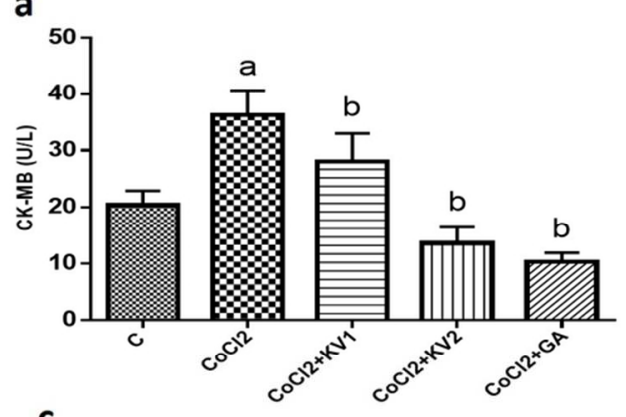

C

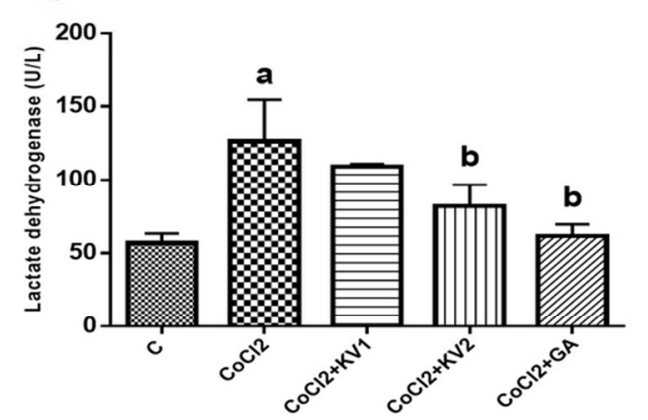

b

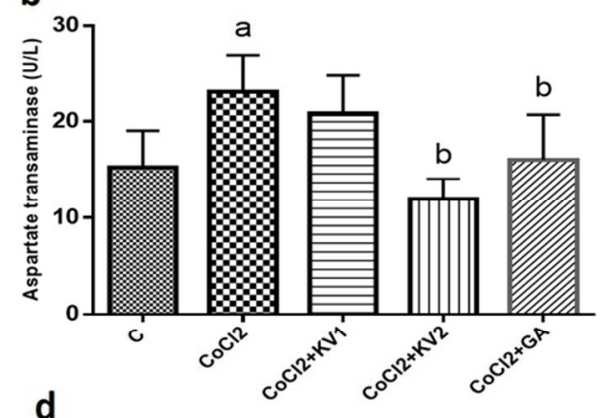

d

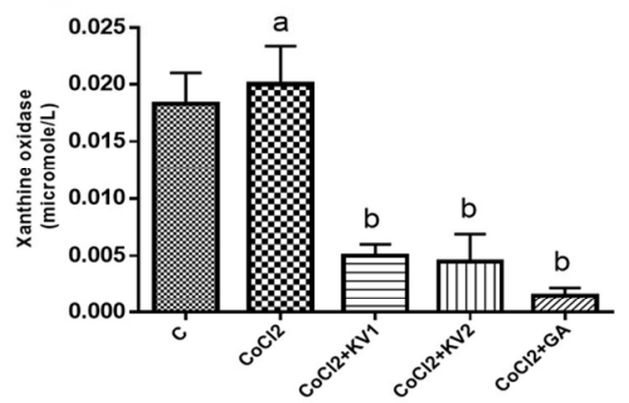

Figure 2: Effect of cobalt chloride with or without Kolaviron or Gallic acid on cardiac marker enzymes Values are presented as mean \pm standard deviation $(n=10)$.

a represents significant difference at $p<0.05$, when compared with control; $b$ represents significant difference at $\mathrm{p}<0.05$, when compared with $\mathrm{CoCl} 2$ group

$87 \times 61 \mathrm{~mm}(300 \times 300 \mathrm{DPI})$ 

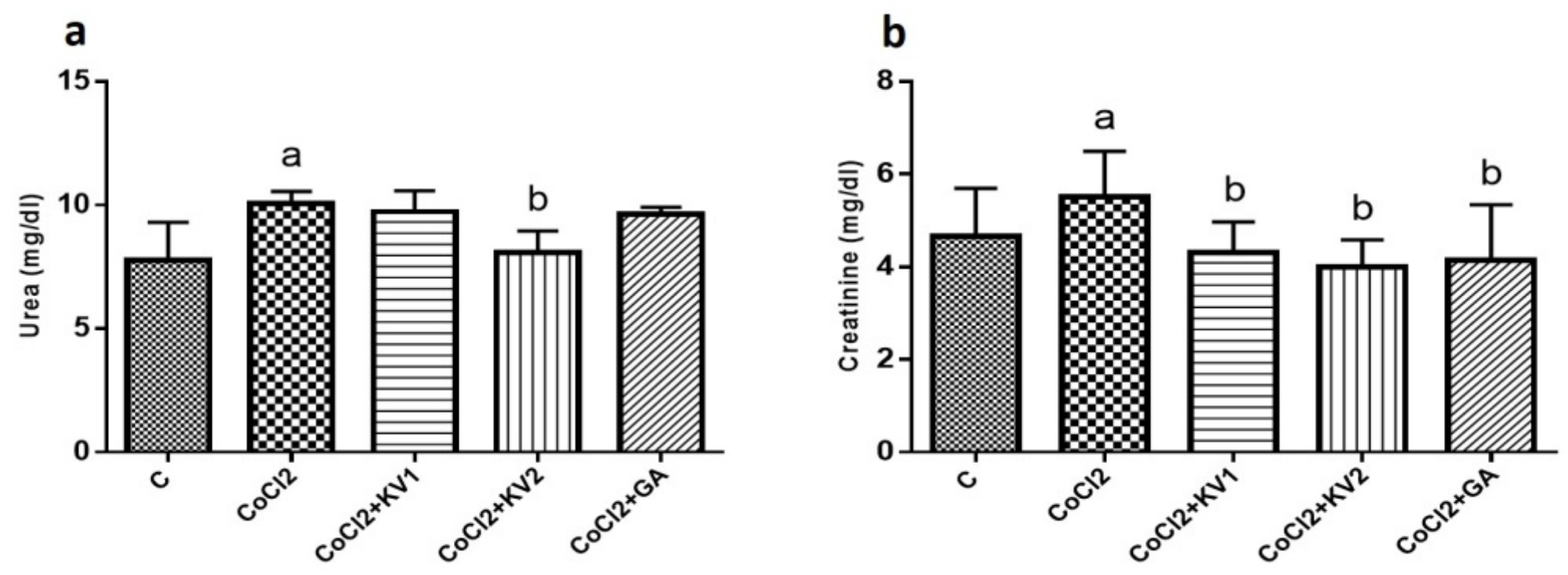

Figure 3. Effect of cobalt chloride with or without Kolaviron or Gallic acid on serum urea and creatinine 


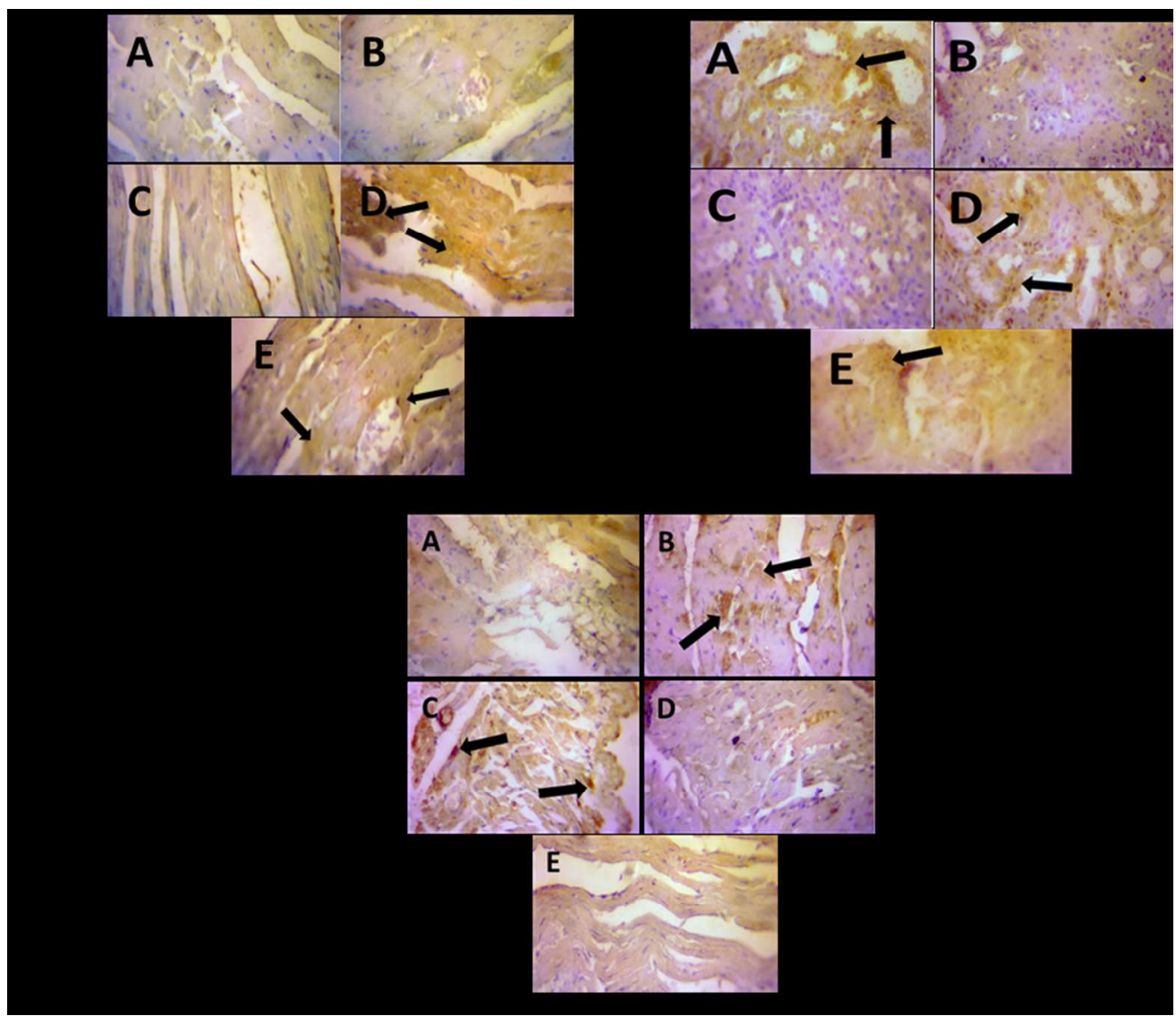

Figure 4: Immunohistochemical staining patterns of a.) ERK in cardiac tissues; b.) ERK in kidney tissues, and c.) CRP in cardiac tissues, of rats exposed to cobalt chloride with or without treatment with Kolaviron and Gallic acid.

$\mathrm{A}=$ Control; $\mathrm{B}=\mathrm{CoCl} 2$ alone $\mathrm{C}=\mathrm{CoCl} 2+\mathrm{KV}(100 \mathrm{mg} / \mathrm{kg}) ; \mathrm{D}=\mathrm{CoCl} 2+\mathrm{KV}(200 \mathrm{mg} / \mathrm{kg}) ; \mathrm{E}=\mathrm{CoCl} 2+$ Gallic acid $(120 \mathrm{mg} / \mathrm{kg})$. Intensity of staining is indicated with black arrows

$81 \times 70 \mathrm{~mm}(300 \times 300$ DPI $)$ 


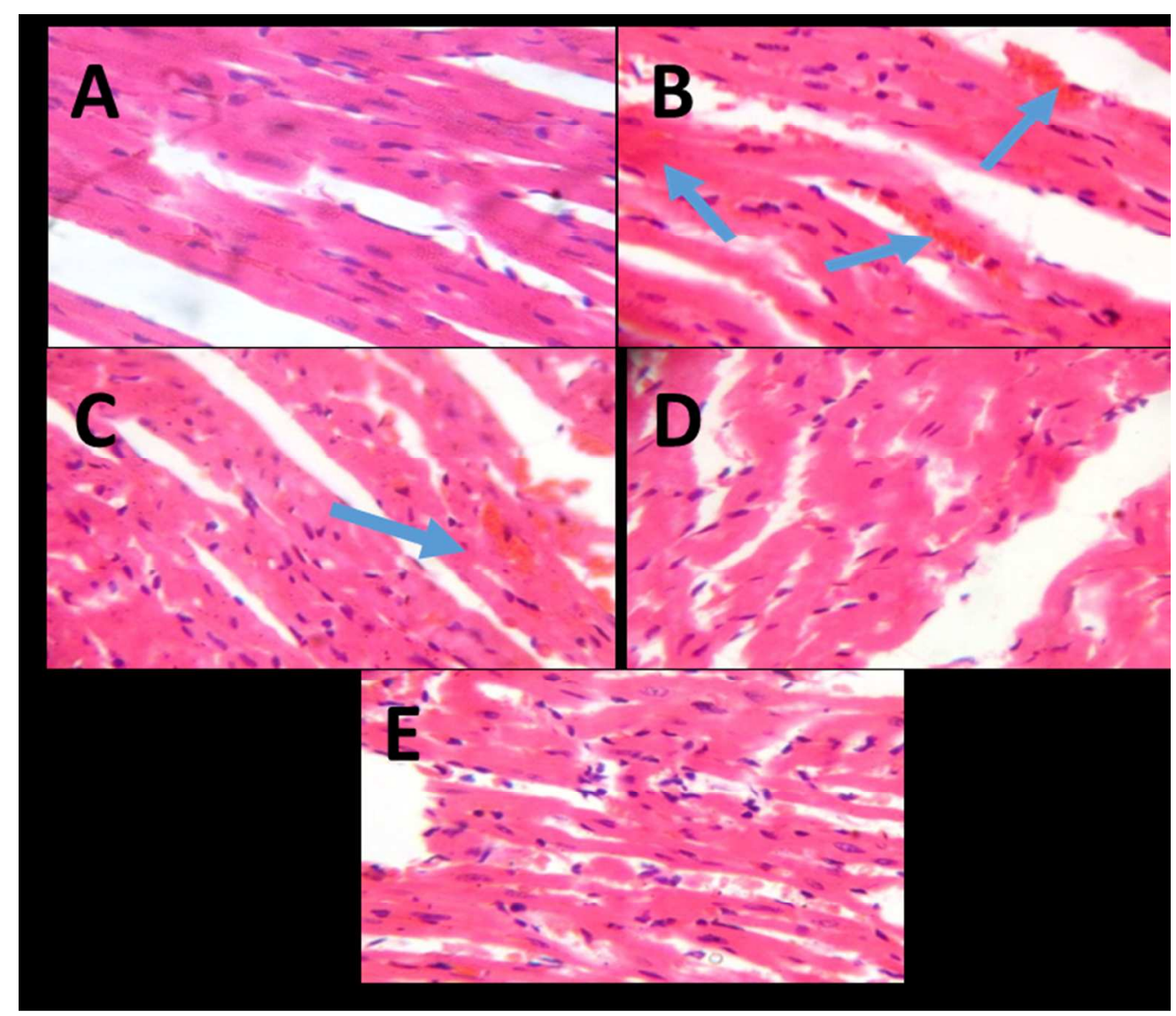

Figure 5: Photomicrographs of heart sections of rats exposed to cobalt chloride with or without treatment with Kolaviron and Gallic acid.

$\mathrm{A}=$ Control; $\mathrm{B}=\mathrm{CoCl} 2$ alone $; \mathrm{C}=\mathrm{CoCl} 2+\mathrm{KV}(100 \mathrm{mg} / \mathrm{kg}) ; \mathrm{D}=\mathrm{CoCl} 2+\mathrm{KV}(200 \mathrm{mg} / \mathrm{kg}) ; \mathrm{E}=\mathrm{CoCl} 2+$ Gallic acid $(120 \mathrm{mg} / \mathrm{kg})$. Hemorrhagic lesions in the myocardium are indicated with blue arrows.

$67 \times 58 \mathrm{~mm}(300 \times 300 \mathrm{DPI})$ 


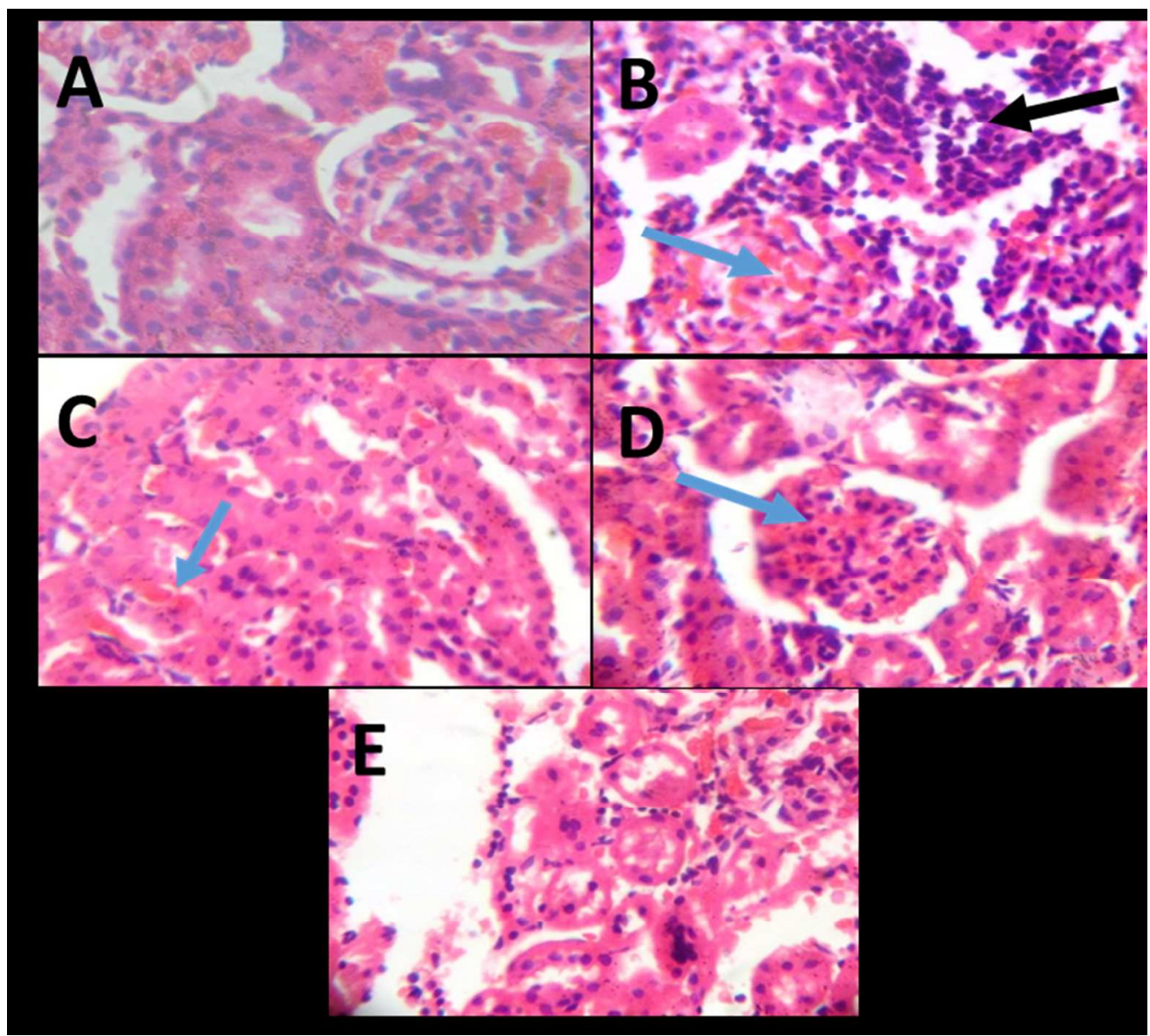

Figure 6: Photomicrographs of kidney sections of rats exposed to cobalt chloride with or without treatment with Kolaviron and Gallic acid.

$\mathrm{A}=$ Control; $\mathrm{B}=\mathrm{CoCl} 2$ alone; $\mathrm{C}=\mathrm{CoCl} 2+\mathrm{KV}(100 \mathrm{mg} / \mathrm{kg}) ; \mathrm{D}=\mathrm{CoCl} 2+\mathrm{KV}(200 \mathrm{mg} / \mathrm{kg}) ; \mathrm{E}=\mathrm{CoCl} 2+$ Gallic acid $(120 \mathrm{mg} / \mathrm{kg})$. Hemorrhagic lesions and congested vessels are indicated with blue arrows; black arrows show severe inflammatory cell infiltration.

$69 \times 62 \mathrm{~mm}(300 \times 300 \mathrm{DPI})$ 